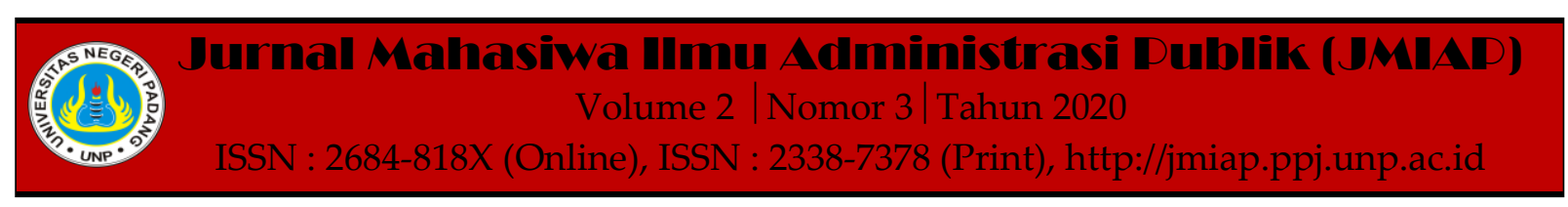

\title{
PENGARUH BUDAYA KERJA DAN KEPUASAAN KERJA TERHADAP KINERJA PEGAWAI DI KECAMATAN SUNGAI GERINGGING
}

\author{
Siti Fatimah ${ }^{1(a)}$, Aldri Frinaldi ${ }^{2(b)}$ \\ ${ }^{1}$ Jurusan Ilmu Administrasi Negara, Universitas Negeri Padang \\ ${ }^{2}$ Jurusan Ilmu Administrasi Negara, Universitas Negeri Padang \\ a) sitifatimah.150927@gmail.com, ${ }^{\text {b) }}$ aldri.fis@unp.ac.id
}

\begin{abstract}
This study aimed to determine, and identify whether there was a significant influence of work culture and job satisfaction on employee performance. This study was conducted in Sungai Geringging District. This study applied a quantitative method with associative approach. The sample in this study was a total sampling technique consisted of 74 employees. Data measurement was performed using a Likert scale. Data in this study were collected through questionnaire distributed to respondents. Data analysis was carried out by using classical assumption test and multiple linear regression. The results of this data analysis processing show that there is a positive influence of work culture on employee performance of Adjusted $R$ Square is $0.070 \%$, a significance value of 0.013 is smaller than 0.05. Job satisfaction has a significant effect on the employee performance of Adjusted $R$ Square of $0.360 \%$. Simultaneously work culture and job satisfaction have a significant effect on employee performance by 0.000 less than 0.05 .
\end{abstract}

Keywords : Work Culture, Job Satisfaction, Employee Performance

Corresponding author. Email. sitifatimah.150927@gmail.com

How to cite this article. Fatimah, S \& Frinaldi, A. (2020). Pengaruh Budaya Kerja dan Kepuasaan Kerja terhadap Kinerja Pegawai di Kecamatan Sungai Geringging. Jurnal Mahasiwa Ilmu Administrasi Publik (JMIAP) Jurusan Ilmu Administrasi Negara Fakultas Ilmu Sosial Universitas Negeri Padang, Volume 2 (3), Hal. 134-144.

http://jmiap.ppj.unp.ac.id

ISSN : 2684-818X (Online), ISSN : 2338-7378 (Print)

Copyright $\odot 2020$. Published by Labor Jurusan Ilmu Administrasi Negara FIS UNP, Padang 


\section{PENDAHULUAN}

Dalam suatu organisasi hal terpenting yang dapat menunjang sebuah organisasi yaitu Sumber Daya Manusia yang memiliki tenaga, bakat maupun ide - ide kreatifitasnya yang bagus, kreatif dan baik. Namun persoalan betapapun memiliki sumber daya keuangan dan teknologi yangdimiliki di dalam organisasi secara sempurna, tanpa memperhatikan adanya kualitas sumber daya manusia yang qualified maka organisasi sulit dalam mencapai tujuannya. Untuk mencapai kesuksesan dapat diwujudkan dengan cara mengelola sumber daya manusia sebaikbaiknya, salah satunya adalah dengan meningkatkan kinerja pegawai (Suhroji,Adha. dkk. 2019).

Dalam beberapa instansi pemerintah pengelolaan terhadap kinerja sudah ditegakkan secara perseorangan untuk agar dapat meningkatkan kualitas pencapaian kinerja pegawai bertujuan menyelenggarakan pemerintahan dan memberikan pelayanan kepada masyarakat oleh sebab ini pegawai diartikan sebagai aset berharga dan utama bagi organisasi, sehingga pegawai tersebut perlu dijaga, dikelola dan dibina secara tepat. Namun tujuan tersebut belum dapat dilaksanakan maupun diterapkan secara menyeluruh di setiap instansi pemerintah. Oleh sebab itu masih terdapat kinerja pegawai seperti yang pemalas, tidak bersemangat melakukan pekerjaan, kurang berbakat, bekerja secara sembarangan, sehingga hal menjadi perhatian khusus pemerintah. (Yuningsih,2017).

Dalam suatu instansi pemerintah, yang mempengaruhi kinerja pegawai salah satunya ialah budaya kerja, menerapkan budaya kerja dengan baik dan diiringi oleh kerjasama sesama pegawai sehingga hal tersebut dapat meningkatkan kinerja pegawai agar lebih baik lagi.

Untuk meningkatkan kinerja pegawai, salah satunya dengan cara meningkatkan kepuasaan kerja pegawai. Setiap pegawai di suatu instansi perlu memperoleh kepuasaan sehingga dapat menciptakan hasil kerja yang baik sehingga pegawai bekerja lebih produktif lagi. Kepuasaan merupakan masalah utama, apabila kepuasaan kerja tidak terpenuhi maka berdampak pada hasil kerja kurang baik, kualitas kerja rendah, dan tujuan yang ingin dicapai tidak terpenuhi dan akhirnya kepuasaan pelanggan maupun konsumen semakin berkurang (Aswadi. 2016).

Persoalan rendahnya kinerja pegawai yang ada di lingkungan kabupaten Padang Pariaman termuat dalam salah satu media massa/berita online yang mengungkapkan berbagai kelemahan pelayanan yang mencerminkan masih rendahnya kualitas kinerja pegawai tersebut. Salah satu media massa online/berita online Investigasi News /www.investigasi.net, Selasa (17/12/2019) yang menjelaskan bahwa:

"Kinerja Pegawai di Kabupaten Padang Pariaman dalam memberikan tugas pelayanan kepada masyarakat masih belum maksimal dan masih mengecewakan. Salah satunya di Kantor $B P N$, Kepala Kantor BPN Padang Pariaman, masuk kantor hanya sekali seminggu. Sehingga tidak mengherankan bila pelayanan pengurusan di kantor BPN Padang Pariaman yang terletak di Korong Padang Baru Nagari Parit Malintang menjadi lamban dan bertele-tele.

Dari berita diatas dapat tergambar oleh peneliti bahwa kinerja pegawai tersebut masih belum maksimal dan masih mengecewakan dalam memberi pelayanan ditandai dengan adanya persoalan dalam pelayanan yang lamban, bertele-tele dan adanya sikap dari pegawai yang masuk kantor hanya sekali seminggu.

Berdasarkan dari pengamatan penulis pada saat melakukan observasi awal tanggal 27 Januari 2020, dapat terlihat jelas permasalahan kinerja pegawai belum berjalan secara maksimal seperti masih terdapat dari beberapa pegawai pada saat jam kerja tidak berada di ruang dan masih ada dari pegawai pulang kerja sebelum jam kerja selesai. Dan peneliti juga melakukan wawancara bersama bapak $\mathrm{M}$ selaku 
pegawai di Kecamatan Sungai Geringging yaitu:

Seperti yang bapak Mjelaskan mengenai kinerja pegawai di Kecamatan Sungai Geringging belum berjalan secara maksimal, karena masih terdapat persoalan yang dapat mengganggu kinerja pegawai seperti: Kurangnya sikap profesional dari beberapa pegawai maupun hampir semua pegawai contohnya apabila ada masalah keluarga selalu dibawa ke lingkungan kerja ataupun dikaitkan dengan pekerjaan, sehingga hal tersebut mengganggu kinerja pegawai.

Berdasarkan pengamatan dan wawancara yang dilakukan penulis kepada bapak M sebagai pegawai di Kecamatan tersebut, dapat penulis gambarkan kinerja pegawai pada Kecamatan Sungai Geringging belum berjalan secara maksimal, hal ini disebabkan ada beberapa persoalan yaitu: masih terdapatnya dari beberapa pegawai yang tidak disiplin terhadap jam kerja, masih terdapat pegawai tidak mengetahui pekerjaannya (tanggung jawab atas pekerjaanya) sehingga hal tersebut menurunkan kinerja masih ada dari pegawai yang mengkaitkan masalah keluarga dengan pekerjaan kantor, sehingga pegawai tersebut tidak fokus dalam melakukan pekerjaannya.

Budaya kerja dan Kepuasaan Kerja sangat mempengaruhi kinerja pegawai, apabila budaya kerja tidak diterapkan dengan baik, maka dapat menurunkan kinerja, sehingga kepuasaan kerja tidak dirasakan pegawai juga mempengaruhi kinerja pegawai. Untuk memperjelas hal tersebut penulis wawancarai Bapak X :

"Pencapaian kinerja pegawai dapat diketahui berdasarkan SKP (Sasaran Kinerja Pegawai), yang dirancang dan dibuat oleh masing-masing pegawai sesuai dengan bidangnya pada awal tahun dan dilaporkan pada akhir tahun kemudian di sahkan oleh pimpinan yang bersangkutan. Karena SKP ini dibuat sendiri oleh masing-masing pegawai maka belum dapat menjamin persentasi kinerja berdasarkan pekerjaan yang telah mereka lakukan, Hal ini disebabkan karena pegawai yang mengisi dan memperkirakan sendiri pencapaian yang telah mereka kerjakan berdasarkan blangko SKP tersebut. Dalam penilaian kinerja pegawai tersebut ada yang menjalankan SKP sesuai target, ada yang lebih bahkan ada juga yang kurang dari target, Apabila pegawai yang melebihi target dan mendapatkan nilai yang sangat baik ataupun baik selama 3 tahun berturutturut maka dapat meningkatkan promosi jabatan, Nah bagi yang tidak melebihi bahkan kurang dari target maka hal itu dapat mempengaruhi peningkatan promosi jabatan.

Berdasarkan permasalahan di atas dapat penulis gambarkan bahwa kinerja pegawai di Kecamatan Sungai Geringging belum berjalan maksimal terlihat dari penjelasan diatas, oleh sebab itu perlu di tingkatkan dan diperbaiki lagi kinerja pegawai. Dari permasalahan yang telah dikemukakan oleh penulis di atas maka peneliti mempunyai ide untuk melakukan penelitian dengan topik "Pengaruh Budaya Kerja dan Kepuasaan Kerja terhadap Kinerja Pegawai di Kecamatan Sungai Geringging Kabupaten Padang Pariaman".

Berdasarkan latar belakang di atas, maka rumusan masalahnya ialah: a) apakah terdapat pengaruh positif dan signifikan variabel budaya kerja terhadap variabel kinerja pegawai di Kecamatan Sungai Geringging? b) apakah terdapat pengaruh kepuasaan kerja terhadap kinerja pegawai di Kecamatan Sungai Geringging? c) apakah terdapat pengaruh antara budaya kerja dan kepuasaan kerja terhadap kinerja pegawai di Kecamatan Sungai Geringging? Tujuan dalam penelitian ini ialah untuk mengetahui pengaruh budaya kerja terhadap kinerja pegawai, pengaruh kepuasaan kerja terhadap kinerja pegawai dan mengetahui pengaruh semua variabel secara simultan terhadap kinerja pegawai. 


\section{TINJAUAN PUSTAKA}

\section{Konsep Kinerja Pegawai}

Pada setiap organisasi kinerja merupakan salah satu faktor pendukung dan penunjang untuk mencapai suatu keberhasilan organisasi. Oleh sebab itu semua organisasi selalu berusaha untuk meningkatkan kinerja pegawainya agar tujuan dan keinginan organisasi sebelumnya dapat tercapai. Tujuan pencapaian kinerja pegawai sangatlah diperlukan, sebab dengan adanya pencapaian kinerja tersebut dapat mengetahui seberapa jauh kemampuan dari diri seorang pegawai untuk menyelesaikan pekerjaan yang diberikan kepadanya.

Sumardjo (2018:193) mengemukakan kinerja ialah hasil kerja yang sudah dicapai pegawai dalam menjalankan tugas dan pekerjaannya pada organisasi. Kinerja diartikan sebagai perwujudan dari bakat dan kemampuan dalam bentuk nyata. Bernardin dan Russel dalam Yeremias. (2008: 210) mengemukakan definisi kinerja sebagai hasil yang sudah dicapai dari fungsi pekerjaan dalam jangka waktu yang tertentu. Hasil tersebut seperti kemampuan, keahlian dan keinginan yang dicapai.

Rivai dan Basri dalam Iwan, (2018) mendefinisikan mengenai kinerja sebagai tingkat keberhasilan seseorang dari hasil melaksanakan tugas dan pekerjaan melalui standar kerja, target maupun sasaran dan kriteria yang telah ditetapkan secara bersama dalam periode tertentu. Kinerja pegawai haruslah tersusun secara berkesinambungan dan ditingkatkan lagi dengan baik, karena peningkatan kinerja pegawai bukan persoalan seketika melainkan harus sesuai dengan nilai - nilai Pancasila dan Undang - Undang Dasar 1945.

Dari penjelasan diatas mengenai budaya kerja, maka dapat peneliti definisikan kinerja meliputi kualitas dan kuantitas dari hasil kerja (output) pegawai yang bersifat perseorangan maupun berkelompok untuk melakukan suatu aktivitas dalam waktu (periode) tertentu diperoleh dari proses belajar serta berkeinginan untuk berprestasi agar ujuan sebelumya dapat tercapai.

Indikator yang dipakai dalam mengukur kinerja pegawai di penelitian (Sumardjo.2018:199) yaitu:

1) Kuantitas Pekerjaan, bertujuan untuk mengetahui jumlah pekerjaan yang dapat diselesaikan pada waktu yang telah ditentukan.

2) Kualitas Pekerjaan, berguna untuk mengetahui ketelitian,keseriusan kerapian, dan kelengkapan dalam menyelesaikan pekerjaan.

3) Kemandirian, berhubungan dengan kemampuan pegawai untuk bekerja dan mengemban tugas secara mandiri ataupun berkaitan dengan kesadaran atau kepercyaan dalam hal kehadiran.

4) Inisiatif, bertujuan agar pegawai berfikir dan kesediaan untuk menerima tanggung jawab.

5) Adaptabilitas, bertujuan agar pegawai memiliki kemampuan untuk beradaptasi dengan lingkungan setempat.

6) Kerja Sama ialah kemampuan pegawai untuk dapat bekerja sama dengan pimpinan, atasan, dan orang lain dengan sepenuh hati.

\section{Konsep Kepuasaan Kerja}

Dalam meningkatkan kinerja pegawai, faktor lainnya yang menjadi pendukung ialah Kepuasaan kerja. Kepuasaan kerja dapat diartikan sebagai salah satu faktor yang mampu membentuk organisasi yang baik dan menciptakan kinerja pegawai yang optimal. Abdurrahmat (2006:175) salah satu pendorong untuk meningkatkan kinerja pegawai ialah dengan cara meningkatkan kepuasaan kerja pegawai tersebut. Kinerja karyawan dapat dikatakan baik, apabila kepuasan kerja yang dirasakan oleh karyawan juga semakin baik. Dengan kata lain, kinerja karyawan yang baik dapat dipengaruhi kepuasan kerja pada diri karyawan. Keberhasilan suatu organisasi dipengaruhi oleh kinerja pegawai, oleh sebab itu setiap organisasi akan berusaha untuk meningkatkan kinerja pegawainya agar tujuan yang telah di tetapkan tecapai 
dengan baik. Sutrisno (2009:74) mengartikan kepuasaan kerja ialah suatu sikap dan prilaku seseorang terhadap pekerjaan yang berhubungan pada situasi dan kondisi kerja, adanya silaturrahmi, terjalin kerja sama antara pegawai satu dengan pegawai lain, tunjangan yang diterima atas pekerjaan sesuai dengan pecapaian target.

Wirawan dalam Iwan (2018) mengartikan kepuasaan kerja merupakan pandangan seseorang mengenai pekerjaannya yang dilihat dari berbagai aspek, seperti perasaan dan sikap seseorang terhadap pekerjaanya. Apabila seseorang merasakan rasa puas terhadap pekerjaan maka akan termotivasi untuk melaksanakan pekerjaannya sehingga menghasilkan kinerjanya tinggi, sebaliknya jika tidak merasa puas puas terhadap pekerjaannya maka ia tidak akan termotivasi untuk melaksanakan pekerjaan dan kinerjanya rendah.

Dengan demikian, dapat diartikan kepuasaan kerja ialah cara pandang seseorang terhadap pekerjaannya baik dinilai dari bentuk positif ataupun negarif. Indikator yang digunakan untuk mengukur kepuasaan kerja dalam penelitian ini Sutrisno (2009:80) yaitu:

1) Kepuasaan psikologik, berhubungan dengan jiwa pegawai dalam bekerja seperti ketentraman, bakat, keterampilan, penghargaan maupun umur merupakan faktor yang berhubungan dengan kejiwaan karyawan (meliputi ketentraman dalam kerja, bakat dan keterampilan, penghargaan dan umur).

2) Kepuasaan sosial, merupakan faktor yang berkaitan dengan orang banyak (interaksi sosial) yang terjalin secara langsung dan tidak secara langsung, baik sesama karyawan maupun dengan atasannya.

3) Kepuasaan fisik, faktor yang berhubungan dengan jenis pekerjaan, pengaturan waktu kerja dan waktu istirahat, perlengkapan kerja, keadaan ruang, suhu, penerangan, pertukaran udara, kondisi kesehatan karyawan, umur dan sebagainya).

4) Kepuasaan finansial, faktor yang berhubungan mengenai jaminan sosial, seperti Gaji, tunjangan, fasilitas yang diberikan, promosi dan sebagainya).

\section{Konsep Budaya Kerja}

Dalam suatu instansi pemerintah salah satu faktor yang mempengaruhi kinerja pegawai ialah budaya kerja, faktor tersebut sangat erat kaitannya dalam meningkatkan kinerja pegawai, sebab dengan tercapainya budaya kerja yang baik dan ditunjang oleh kerjasama dengan sesama pegawai, maka akan tercapai hasil yang dapat meningkatkan kinerja kerja pegawai, (Tika, 2008:120).

Triguno dalam Aldri (2011:53) mengartikan mengenai budaya kerja ialah filsafat yang berlandaskan pada pandangan hidup seperti kebiasaan berubah menjadi sifat dan pendorong untuk membudaya didalam kehidupan berkelompok seperti masyarakat dan organisasi akan tergambarkan melalui keyakinan, cita - cita dan kelakuan sehingga terwujud kerja maupun bekerja.

Selanjutnya Aldri mengemukakan budaya kerja ialah suatu hal yang bisa dilhat secara langsung maupu tidak langsung dari seseorang melalui pandangan perspektif nilai, mengetahui cara bekerja dengan baik, memiliki pola pikir, dan perilaku setiap orang maupun sekelompok orang untuk melakukan suatu pekerjaan.

Dari definisi budaya kerja diatas, maka dapat di artikan budaya kerja sebagai Falsafah, nilai maupun kebiasaan yang terdapat dalam diri seseorang, kelompok maupun organisasi sehingga menjalankan pekerjaan dengan semestinya agar terciptanya kinerja dengan baik.

Untuk mengukur budaya kerja dalam penelitian ini, dipakai beberapa indikator (Aldri.2017) sebagai berikut:

1) Kepemimpinan

Kepemimpinan yang yang dimaksud ialah kemampuan yang digunakan 
untuk mempengaruhi seseorang dalam pencapaian tujuan organsisasi.

2) Penampilan

Penampilan yang dimaksud seperti pemilihan warna seragam, potongan rambut, dan bahasa tubuh aparatur. sehingga dapat membangun citra yang positif dan baik dari pegawai di mata publik.

3) Kesadaran akan waktu

Kesadaran yang dimaksud ialah seperti disiplin akan waktu dan tidak menunda - nunda dalam menyelesaikan pekerjaan.

4) Komunikasi

Interaksi yang terjadi antara satu orang pegawai atau lebih baik dalam bentuk bertutur kata, berbicara dan berekspresi untuk menyampaikan infornasi atau pesan agar tujuan organisasi tercapai.

5) Penghargaan dan pengakuan

Berkaitan dengan reward bagi dari aparatur yang mempunyai prestasi kerja seperti: Mendapatkan promosi jabatan, dan kesempatan mengikuti pendidikan.

6) Nilai dan kepercayaan

Suatu keyakinan atau pedoman bagi pegawai untuk melaksanakan pekerjaannya.

\section{METODE PENELITIAN}

Penelitian ini peneliti menerapkan metode kuantitatif dengan pendekatan asosiatif. Penelitian ini diadakan di Kecamatan Sungai Geringging Kabupaten Padang Pariaman. Penentuan responden menggunakan total sampling yaitu mengambil seluruh jumlah pegawai yang ada di Kecamatan Sungai Geringging dengan jumlah 74 orang pegawai.

Alat pengumpulan data ialah dengan cara menyebarkan angket/kuesoiner kepada responden dan menggunakan pengukuran skala likert. Cara pengolahan dan analisis data dilakukan melalui uji asumsi klasik dan uji regresi berganda.

\section{HASIL DAN PEMBAHASAN}

Adapun hasil dari penelitian ini digunakan untuk menjawab rumusan masalah pada artikel ini. Untuk itu dapat dilihat hasil analisis data oleh peneliti sebagai berikut :

\section{Uji Asumsi Klasik}

\section{a. Uji Normalitas}

Histogram

DependentVariable: Abs_RES

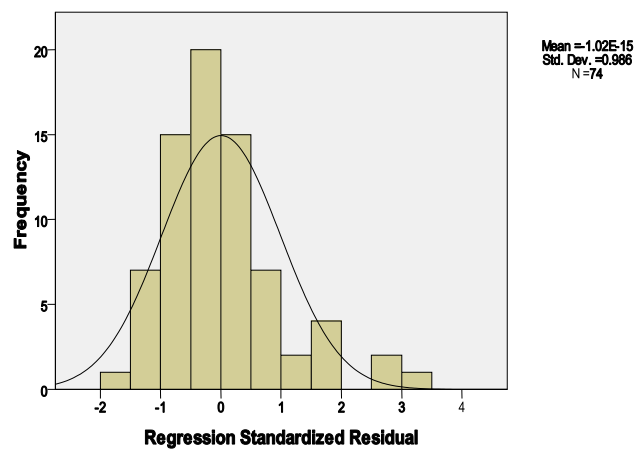

Sumber: Data Olahan Penelitian, 2020

Berdasarkan dari gambar output diatas diketahui pada data ini berdistribusi normal, karena persebaran data telah membentuk kurva secara normal terlihat pada hasil gambar regression standardized residual.

\section{b. Uji Multikolinieritas}

Berdasarkan penelitian ini dapat kita ketahui nilai VIF menunjukan tingkat multikoleniaritas yang rendah. Sedangkan untuk nilai VIF dari penelitian ini memiliki nilai kecil dari 10. Maka dari itu dapat dijelaskan pada penelitian ini tidak terjadi permasalahan multikoloniertitas.

\section{c. Uji Heteroskedastistis}

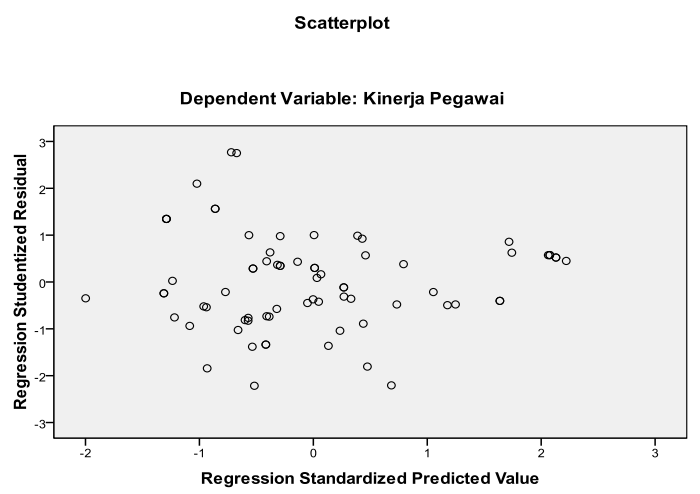

Sumber: Data Olahan Penelitian, 2020 
Dari hasil output diatas maka dapat dilihat bahwa data pada penelitian ini digambarkan dengan bentuk titik - titik. Semua titik tersebar di atas angka nol digambarkan dengan bentuk titik - titik. Semua titik tersebar di atas angka nol terdapat didaerah sumbu Y.

Titik tersebut terletak diatas dan dibawah ol pada sumbu. Titik tidak akan membentuk suatu pola tertentu Sehinggga dapat dimaknai data penelitian ini tidak terdapat heterokrdastisitas. Dengan kata lain, tidak terdapat adanya penyimpangan yang terjadi antara semua variabel penelitian ini.

\section{d. Uji Linearitas}

Normal P-P Plot of Regression Standardized
Residual

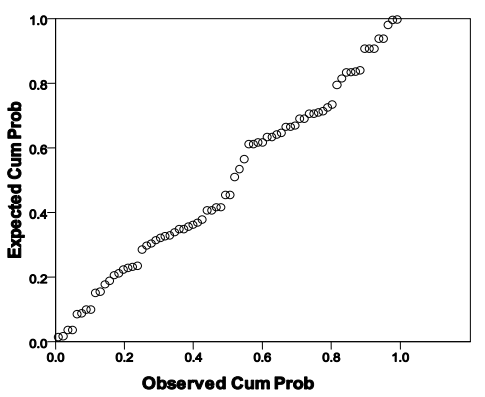

Sumber: Data Olahan Penelitian, 2020

Dari hasil output di atas, dapat disimpulkan hasil data terdistribusi dengan normal, ditandai dengan adanya gambar titik - titik disepanjang garis. Hal ini menyatakan data telah memenuhi syarat untuk dilakukan uji regresi, karena data tidak memiliki gangguan pada pendistribusiannya.

\section{UJI HIPOTESIS \\ REGRESI LINEAR BERGANDA \\ Uji Hipotesis ( Uji T Parsial)}

\section{Tabel 1. Hasil Uji T Variabel X1 Terhadap Y}

Coefficients $^{\mathrm{a}}$

\begin{tabular}{|c|c|c|c|c|c|}
\hline \multirow[b]{2}{*}{ Model } & \multicolumn{2}{|c|}{$\begin{array}{l}\text { Unstandardized } \\
\text { Coefficients }\end{array}$} & $\begin{array}{c}\text { Standar } \\
\text { dized } \\
\text { Coeffici } \\
\text { ents }\end{array}$ & \multirow[b]{2}{*}{$\mathrm{T}$} & \multirow[b]{2}{*}{ Sig. } \\
\hline & B & Std. Error & Beta & & \\
\hline $1 \quad$ (Constant) & 2.236 & .367 & & 6.086 & .000 \\
\hline $\begin{array}{l}\text { Budaya } \\
\text { Kerja }\end{array}$ & .309 & .121 & .287 & 2.545 & .013 \\
\hline
\end{tabular}

Sumber: Data Olahan Penelitian, 2020

Dari data hasil temuan diatas, diketahui nilai signifikansi variabel budaya kerja ialah sebesar 0.013 lebih kecil dari 0.05. Oleh sebab itu budaya kerja memiliki pengaruh terhadap kinerja pegawai.

\section{Tabel 2. Hasil Uji T Variabel X2 Terhadap Y}

Coefficients $^{\mathrm{a}}$

\begin{tabular}{|c|c|c|c|c|c|}
\hline \multirow[b]{2}{*}{ Model } & \multicolumn{2}{|c|}{$\begin{array}{l}\text { Unstandardized } \\
\text { Coefficients }\end{array}$} & \multirow{2}{*}{\begin{tabular}{|c}
$\begin{array}{c}\text { Standar } \\
\text { dized } \\
\text { Coeffic } \\
\text { ients }\end{array}$ \\
Beta
\end{tabular}} & \multirow[b]{2}{*}{$\mathrm{T}$} & \multirow[b]{2}{*}{ Sig. } \\
\hline & B & $\begin{array}{l}\text { Std. } \\
\text { Error }\end{array}$ & & & \\
\hline (Constant) & 1.188 & .308 & & 3.857 & .000 \\
\hline $\begin{array}{l}\text { Kepuasan } \\
\text { Kerja }\end{array}$ & .641 & .099 & .607 & 6.480 & .000 \\
\hline
\end{tabular}

a. Dependent Variable: Kinerja Pegawai

Sumber: Olahan Data Penelitian, 2020

Dari hasil output diatas, diketahui budaya kerja memiliki nilai signifikansi ialah sebesar 0.000 kecil dari 0,05, sehingga 
Siti Fatimah, Aldri Frinaldi I Pengaruh Budaya Kerja dan Kepuasaan Kerja terhadap Kinerja Pegawai di Kecamatan Sungai Geringging

budaya kerja berpengaruh terhadap kinerja pegawai.

\section{Koefisien Determinasi}

\section{Tabel 3. Hasil Koefisien Determinasi Variabel XI Terhadap Y}

\begin{tabular}{|l|r|r|r|r|}
\hline Model & \multicolumn{1}{|c|}{ R } & R Square & $\begin{array}{c}\text { Adjusted R } \\
\text { Square }\end{array}$ & $\begin{array}{r}\text { Std. Error of } \\
\text { the Estimate }\end{array}$ \\
\hline 1 & $.287 \mathrm{a}$ & .083 & .070 & .52022 \\
a. Predictors: (Constant), Budaya Kerja \\
b. Dependent Variable: Kinerja Pegawai
\end{tabular}

Sumber: Olahan Data Penelitian, 2020

Dari hasil output di atas dapat kita ketahui terdapat nilai Adjusted $R$ Square ialahsebesar 0,070 artinya terdapat pengaruh budaya kerja terhadap kinerja pegawai di Kecamatan Sungai Geringging $7,0 \%$. Sedangkan sisanya 93,0\% berpengaruh pada penelitian lain.

\section{Tabel 4. Hasil Koefisien Determinasi} Variabel X2 Terhadap Y

Model Summary ${ }^{b}$

\begin{tabular}{|l|r|r|r|r|}
\hline Model & \multicolumn{1}{|c|}{$\mathrm{R}$} & R Square & $\begin{array}{c}\text { Adjusted R } \\
\text { Square }\end{array}$ & $\begin{array}{c}\text { Std. Error of } \\
\text { the Estimate }\end{array}$ \\
\hline 1 & $.607^{\mathrm{a}}$ & .368 & .360 & .43166 \\
\hline
\end{tabular}

a. Predictors: (Constant), Kepuasan Kerja

b. Dependent Variable: Kinerja Pegawai

Sumber: Olahan Data Penelitian, 2020

Berdasarkan hasil output di atas dapat kita ketahui terdapat nilai Adjusted $R$ Square yaitu sebesar 0,360 yang artinya terdapat pengaruh kepuasaan kerja terhadap kinerja pegawai di Kecamatan Sungai Geringging $36,0 \%$ Sedangkan Sisanya $64,0 \%$ berpengaruh pada penelitian lain.
Tabel 5. Hasil Koefisien Determinasi Varibel X1, X2 Terhadap Y

Model Summaryb

\begin{tabular}{|r|r|r|r|r|}
\hline Model & \multicolumn{1}{|c|}{$\mathrm{R}$} & $\begin{array}{c}\mathrm{R} \\
\text { Square }\end{array}$ & $\begin{array}{c}\text { Adjusted R } \\
\text { Square }\end{array}$ & $\begin{array}{c}\text { Std. Error of } \\
\text { the Estimate }\end{array}$ \\
\hline 1 & $.624^{\mathrm{a}}$ & .389 & .372 & .42753 \\
\hline
\end{tabular}

a. Predictors: (Constant), Kepuasan Kerja , Budaya Kerja

b. Dependent Variable: Kinerja Pegawai

Sumber: Olahan Data Penelitian, 2020

Dari hasil output diatas, menjelaskan besarnya nilai Adjusted $\mathrm{R}$ ialah sebesar $0,372 \%$. Artinya variabel budaya kerja dan kepuasaan kerja secara bersama - sama mempengaruhi kinerja pegawai di Kecamatan Sungai Geringging sebesar $37,2 \%$, sedangkan sisanya $62,8 \%$ berpengaruh pada penelitian lain.

\section{Uji Simultan (F) Variabel X1 dan X2 Terhadap $\mathbf{Y}$}

Tabel 5. Hasil Uji F X1 dan X2 Terhadap Y

ANOVA $^{b}$

\begin{tabular}{|l|r|r|r|r|r|}
\hline Model & $\begin{array}{r}\text { Sum of } \\
\text { Squares }\end{array}$ & Df & $\begin{array}{c}\text { Mean } \\
\text { Square }\end{array}$ & F & Sig. \\
\hline $1 \quad$ Regression & 8.261 & 2 & 4.130 & 22.598 & $.000^{\mathrm{a}}$ \\
Residual & 12.978 & 71 & .183 & & \\
Total & 21.239 & 73 & & & \\
\hline
\end{tabular}

a. Predictors: (Constant), Kepuasan Kerja , Budaya Kerja

b. Dependent Variable: Kinerja Pegawai

\section{Sumber: Olahan Data Penelitian, 2020}

Hasil output uji simultan variabel $\mathrm{X} 1$ dan $\mathrm{X} 2$ terhadap $\mathrm{Y}$ di atas menjelaskan terdapat pengaruh signifikan budaya kerja signifikan budaya kerja dan kepuasaan kerja sebesar 0.000 lebih kecil dari 0.05. 


\section{Pengaruh Budaya Kerja terhadap Kinerja Pegawai di Kecamatan Sungai Geringging}

Hasil penelitian menunjukkan adanya pengaruh signifikan secara parsial maupun simultan yang telah dijelaskan pada tabel diatas. Budaya kerja memiliki pengaruh sebesar $0,070 \%$ dan nilai signifikansi adalah 0,013 terhadap kinerja pegawai. Hal ini menguatkan dan membuktikan teori (Tika, 2008:120) salah satu faktor yang mempengaruhi kinerja pegawai ialah budaya kerja, faktor tersebut sangat erat kaitannya dalam meningkatkan kinerja pegawai, oleh sebab itu sebab budaya kerja yang baik dan ditunjang oleh kerjasama dengan sesama pegawai, maka hal tersebut dapat meningkatkan kinerja kerja pegawai.

Dari teori di atas kita ketahui bahwa variabel budaya kerja dapat mempengaruhi kinerja pegawai, karena budaya kerja menerapkan yang baik maka dapat meningkatkan kinerja pegawai.

Hasil penelitian ini sejalan dengan penelitian yang dilakukan oleh Mambang (2015) dengan judul Pengaruh Budaya Kerja Terhadap Kinerja Pegawai di Kantor Kementrian Agama Kabupaten Gunung Mas Provinsi Kalimantan Tengah membuktikan bahwa Budaya kerja berpengaruh positif dan signifikan terhadap kinerja pegawai, semakin tinggi budaya kerja maka kinerja pegawai juga akan tinggi, begitu pula sebaliknya semakin rendah budaya kerja maka semakin rendah pula kinerja pegawai. Selain itu, hasil penelitian yang dilakukan oleh Asyrori (2014) di Kantor Kecamatan Samarinda membuktikan budaya kerja memiliki hubungan yang sedang terhadap nkinerja pegawai, walaupun belum berjalan dengan maksimal seperti masih ada pegawai yang belum sadar akan waktu dalam menyelesaikan suatu pekerjaan. Hasil penelitian lain juga dilakukan oleh Ferdy (2018) di PT. Bank Mandiri Lampung dengan hasil penelitian membuktikan bahwa budaya kerja memiliki pengaruh signifikan terhadap kinerja pegawai.

\section{Pengaruh Kepuasaan Kerja Terhadap kinerja Pegawai di Kecamatan Sungai Geringging}

Hasil penelitian menunjukkan adanya pengaruh positif dan signifikan baik secara parsial dan simultan yang telah dijelaskan pada tabel di atas. Kepuasaan kerja memiliki pengaruh sebesar $0,360 \%$ dan nilai signifikansi ialah 0,000 terhadap kinerja pegawai. Hal ini membuktikan teori Abdurrahmat (2006:175) salah satu pendorong untuk meningkatkan kinerja pegawai adalah dengan meningkatkan kepuasaan kerja pegawai tersebut. Kinerja karyawan dikatakan baik, apabila kepuasan kerja yang dirasakan oleh karyawan juga semakin baik. Dengan kata lain, kinerja karyawan yang baik dapat dipengaruhi kepuasan kerja pada diri karyawan. Keberhasilan suatu organisasi dipengaruhi oleh kinerja pegawai, oleh sebab itu setiap organisasi akan berusaha untuk meningkatkan kinerja pegawainya agar tujuan yang telah di tetapkan tecapai dengan baik. Senada dengan itum enurut Wirawan (2018) menjelaskan Apabila seseorang puas terhadap pekerjaannya ia menyukai dan termotivasi untuk melaksanakan pekerjaannya dan kinerjanya tinggi, sebaliknya jika tidak puas dengan pekerjaannya ia tidak termotivasi untuk melaksanakan pekerjaannya dan kinerjanya rendah.

Berdasarkan teori di atas, secara tidak langsung kepuasaan kerja sangat berpengaruh tehadap kinerja pegawai. Karena kepuasaan kerja merupakan hal yang penting dalam suatu organisasi kondisi menyenangkan atau tidak menyenangkan secara emosional positif yang berasal dari penilaian seseorang atas pekerjaannya atau pengalaman kerjanya. Jika seseorang puas dalam melakukan suatu pekerjaan ataupun suka melakukan 
Siti Fatimah, Aldri Frinaldi I Pengaruh Budaya Kerja dan Kepuasaan Kerja terhadap Kinerja Pegawai di Kecamatan Sungai Geringging

pekerjaan maka akan mengakibatkan kinerjanya semakin meningkat dan sebaliknya. Sehingga dapat dikatakan bahwa kepuasaan kerja memiliki pengaruh sangat besar untuk meningkatkan kinerja pegawai.

Hasil penelitian ini sejalan dengan penelitian yang dilakukan oleh Kurnia (2018) di PT CV Bukit Sanomas bagian produksi menunjukkan adanya pengaruh yang signifikan kepuasaan kerja terhadap kinerja. Kinerja karyawan dikatakan baik, apabila kepuasan kerja yang dirasakan oleh karyawan juga semakin baik. Dengan kata lain, kinerja karyawan yang baik dapat dipengaruhi oleh kepuasan kerja pada diri karyawan. Hal ini juga didukung oleh penelitian yang dilakukan oleh Rizki, Damayanti ( 2018) di Medis Rs Islam Siti Khadijah Palembang menunjukkan adanya pengaruh yang kuat dan signifikan antara kepuasan kerja terhadap kinerja karyawan. Semakin puas seseorang dalam melakukan pekerjaan maka semakin meningkatkan kinerja dan seb2aliknya. Hal ini juga didukung oleh penelitian yang dilakukan oleh Anton Tirta Komara dan Euis Nelliawati ( 2014) Di Lingkungan Rumah Sakit Umum Daerah (Rsud) Kota Bandung menunjukan bahwa adanya pengaruh signifikan antara kepuasaan kerja terhadap kinerja pegawai.

\section{PENUTUP}

Berdasarkan hasil analisis data dan pembahasan yang telah dikemukakan sebelumnya, sehingga dapat penulis simpulkan ialah: Terdapat pengaruh positif dan signifikan budaya kerja terhadap kinerja pegawai, terdapat pengaruh positif dan signifikan kepuasaan kerja terhadap kinerja pegawai, Secara simultan semua variabel terdapat pengaruh positif dan signifikan terhadap kinerja pegawai.

\section{DAFTAR KEPUSTAKAAN}

Abdurrahmat, Fathoni. 2006. Organisasi dan Manajemen Daya Manusia. Jakarta: PT. Rineka Cipta.

Aldri Frinaldi dan Muhammad Ali Embi. 2011. Pengaruh Budaya Kerja Etnik Terhadap Budaya Kerja Keadlan dan Keterbukaam PNS dalam Membangun Masyarakat Madani dan Demokrasi (Studi pada Pemerintahan Kabupaten Pasaman Barat). FIS UNP. Vol X No.1 Tahun 2011.

Aldri, F. 2014. Pengaruh Budaya Kerja Pegawai Negeri Sipil Terhadap Pelayanan Publik Di Dinas Catatan Sipil Dan Kependudukan Kota Payakumbuh. Humanus, XIII (2), 180192.

Aswadi, Lubis. 2016. Pengaruh Budaya Kerja Dan Gaya Kepemimpinan Terhadap Kepuasan Kerja Pegawai Administrasilain Padangsidimpuan. Jurnal Penelitian Ilmu-ilmu Sosial dan Keislaman. Vol. 02 No. 2. Dosen Fakultas Ekonomi dan Bisnis Islam IAIN: Padangsidimpuan.

Iwan, Kurnia Wijaya. 2018. Pengaruh Kepuasan Kerja Terhadap Kinerja Karyawan Cv Bukit Sanomas. Jurnal Agora.Volume 6, Nomor 2. Surabaya: Fakultas Ekonomi, Universitas Kristen Petra.

Suhroji,Adha.2019. Pengaruh Kepuasaan Kerja Terhadap Kinerja Pegawai Pada Dinas Perindustrian, Perdagangan dan Esdm Kabupaten Pandeglag. Jurnal Ekonomi Vokasi. Volume 2, Nomor 1. ISSN. 2622- 4240.

Sumardjo, Mahendro. 2018. Manajemen Pengembangan Sumberdaya Manusia. Jakarta: Alfabeta.

Sutrisno, Edy.2009. Manajemen Sumber 
Siti Fatimah, Aldri Frinaldi I Pengaruh Budaya Kerja dan Kepuasaan Kerja terhadap Kinerja Pegawai di Kecamatan Sungai Geringging

Daya Manusia. Jakarta: Kencana.

T.Hani Handoko dan Rahmawati 2008.

Manajemen Sumber Daya Manusia.

Yogyakarta : BPFE.

Yeremias.T. Keban. 2008. Enam dimensi strategis administrasi publik "konsep, Teori, dan Isu. Yogyakarta: Gaya Media.

Yuningsih, Nining. 2017. Penerapan

Manajemen Kinerja Pegawai Di

Instansi Pemerintah.Jurnal

Pengembangan Wiraswasta. Vol. 19

No.2 Agustus 2018. 